Piotr Dymmel

(Archiwum Państwowe w Lublinie)

Pamięci

Profesora Jerzego Wyrozumskiego, wielkiego znawcy życia i dzieł Jana Długosza

\title{
Życie i twórczość Jana Długosza w bibliografiach opisane*
}

abstrakt: Przedmiotem artykułu jest przegląd bibliografii podmiotowych i przedmiotowych związanych $\mathrm{z}$ Janem Długoszem. W centrum uwagi znajdą się zagadnienia związane z początkami i rozwojem tych bibliografii, ich rodzajami i zawartością oraz rolą i znaczeniem, jakie pełnią w badaniach nad Długoszem. Autor omawia cztery obszary produkcji bibliograficznej związanejz Długoszem. Pierwszy rozpoczął się w XVIII w. i charakteryzował się powstawaniem prac biobibliograficznych, w których łączono zainteresowania biograficzne $\mathrm{z}$ poszukiwaniem rękopiśmiennych zabytków jego twórczości. W latach 70. XIX w. pojawił się drugi obszar związany z tworzeniem bibliografii narodowej piśmiennictwa polskiego. Ważną częścią tego piśmiennictwa były drukowane wydania dzieł Długosza, a później także publikacje jemu poświęcone. Od początku XX w. Długosz trafił do bibliografii opracowywanych przez historyków literatury. Najpierw w znanych bibliografiach obcych niemieckiej Potthasta i francuskiej Chevaliera, aby później wejść na stałe do polskiej produkcji bibliograficznej, tworzonej w różnej postaci przez historyków aż do dziś. Pomimo wielu bibliografii żadna z nich

\footnotetext{
* Artykuł powstał na podstawie wykładu pt. Z prac nad bibliografia podmiotowa i przedmiotowa Jana Dlugosza wygłoszonego przez autora na Wydziale II Historyczno-Filozoficznym PAU 21 III 2014 r. Skrócona wersja referatu została opublikowana pt. Warsztat bibliograficzny badań nad Janem Długoszem, [w:] Jan Długosz - w kręgu badań historyków i literaturoznawców, red. T. Giergiel, Sandomierz 2017, s. 211-223.
} 
nie dostarcza pełnego wykazu literatury Długoszowej, dlatego muszą one być wykorzystywane w sposób komplementarny. Autor wysuwa postulat, aby stworzyć nową bibliografię podmiotowo-przedmiotową, obejmującą całość piśmiennictwa dotyczącego Jana Długosza w postaci elektronicznej jako aplikację internetową. Zapowiada jej ukazanie się w 2019 r.

sŁowa KLuczowe: bibliografia, Jan Długosz, historiografia XIX i XX w., bazy danych.

Rozwój każdej nauki lub jakiegoś obszaru badawczego nierozerwalnie wiąże się z tworzeniem narzędzi bibliograficznych, w których gromadzi się, porządkuje i opisuje powstałe $w$ ich ramach piśmiennictwo. Świadomość potrzeby tworzenia takich narzędzi rodzi się głównie z chwilą intensywnego przyrostu piśmiennictwa, którym zarządzanie, z uwagi na ilość, zróżnicowanie tematyczne, źródła proweniencji, formy piśmiennicze i zapewne wiele innych jeszcze czynników, staje się coraz trudniejsze. Z ulgą przyjmujemy wówczas wszelką pomoc w postaci różnego rodzaju spisów, zestawień, repertoriów i wykazów, które ułatwiają nam poruszanie się w gąszczu publikacji. Podobną drogę do bibliograficznych prac możemy prześledzić dla dlugossianów, czyli piśmiennictwa, które w ciągu pięciu stuleci powstało w związku z zainteresowaniami i badaniami nad życiem i twórczością Jana Długosza. Wzrastająca liczba publikacji drukowanych zaczęła stopniowo uświadamiać potrzebę zebrania i opisania ich z pożytkiem dla badaczy i wszystkich innych osób zainteresowanych Długoszem.

Przedmiotem niniejszego artykułu jest dokonanie przeglądu bibliografii podmiotowych i przedmiotowych związanych z Janem Długoszem. W centrum uwagi znajdą się zagadnienia związane z początkami i rozwojem tych bibliografii, ich rodzajami i zawartością oraz rolą i znaczeniem, jakie pełnią w badaniach nad Długoszem. Rozważania te będą nas prowadzić do odpowiedzi na pytanie o potrzebę i możliwości stworzenia nowoczesnego i pełnego kompendium bibliograficznego, związanego z osobą średniowiecznego historyka.

Życie i twórczość Jana Długosza budziły zainteresowanie u ludzi już mu współczesnych. Być może jeszcze za jego życia lub zaraz po jego śmierci nieznany do dziś autor napisał w języku łacińskim, utrzymaną w duchu humanistycznym, pierwszą jego biografię zatytułowaną Vita Ioannis Dlugosch Senioris 
canonici Cracoviensis ${ }^{1}$. To niewielkie rozmiarami dzieło rozpoczyna pośmiertną sławę Długosza w piśmiennictwie, która od schyłku XV w. trwa nieprzerwanie do dziś. W ciągu ponad 500 lat powstał całkiem pokaźnych rozmiarów dorobek pisarski związany z Długoszem, który stale jest powiększany. Obecnie można go szacować na ok. 2000 pozycji, biorąc pod uwagę tylko te, których tematyka prac jest bezpośrednio zorientowana na osobę i pisarstwo Długosza. Wyraźnie go powiększają publikacje odwołujące się do dzieł Długosza traktowanych tylko jako źródło poznania historycznego badanych problemów.

\section{Biobibliografia - w kręgu rękopisów}

Historycy i pisarze z okresu staropolskiego uważali Długosza za jednego z najważniejszych autorów, chociaż nie wszystkie jego dzieła były znane w jednakowym stopniu, a niektóre nie były mu nawet przypisywane. Szczególnie duże zainteresowanie budziły jego Annales seu cronicae incliti Regni Poloniae, których przetłumaczenie na język polski zalecał w II połowie XVI w. Maciej Stryjkowski ${ }^{2}$. Niestety, nikt tego pomysłu wówczas nie podchwycił, ale bynajmniej, ani sama łacina, ani duży rozmiar dzieła, nie stanęły na przeszkodzie szerokiemu rozpowszechnieniu Roczników. Należy podkreślić, że wyszło ono daleko poza potrzeby i zainteresowanie pisarzy historycznych, stając się szerszym zjawiskiem kulturowym. Świadectwem żywej recepcji tego dzieła jest duża liczba rękopiśmiennych kopii sporządzonych do początku XVIII w. Do dziś zachowało się ok. 60 odpisów o różnym zakresie zawartości tekstu, drugie tyle znanych jest pośrednio ${ }^{3}$. Dość wcześnie podjęto też zamiar wydania Roczników drukiem, jednak pierwszy ich wydawca, Jan Szczęsny Herburt, zdołał wydać w 1615 r. tylko sześć pierwszych ksiąg. Na przeszkodzie pełnej edycji stanął królewski zakaz i konfiskata druku, ale przyczyny tej decyzji nie są do końca dobrze znane. $\mathrm{Na}$

\footnotetext{
1 Wydawca Vita Dlugossi Mieczysław Brożek przed ponad 50 laty dowodził, że autorem dzieła był Kallimach - M. Brożek, Czy Filip Kallimach jest autorem Żywotu Długosza?, „Zeszyty Naukowe Uniwersytetu Jagiellońskiego" Prace historycznoliterackie, z. 3, Filologia, z. 5, 1959, s. 11-6o. Z kolei ostatnio przywołano ważne argumenty wskazujące na autorstwo Jakuba z Szadka - zob. M. Koczerska, Kto jest autorem Żywotu Długosza?, [w:] Venerabiles, nobiles et honesti. Studia $z$ dziejów społeczeństwa Polski średniowiecznej, Toruń 1997, s. 507-520.

2 H.-J. Bömelburg, Polska myśl historyczna a humanistyczna historia narodowa (1500-1700), Kraków 2011, s. 63.

3 P. Dymmel, Tradycja rękopiśmienna Roczników Jana Długosza. Studium analityczne ksiąg X-XII, Warszawa 1992, s. 9-15.
} 
całość drukowanego dzieła przyszło jeszcze poczekać prawie 100 lat, do czasu, gdy wydawcy z Lipska w latach 1711-1712 opublikowali wszystkich 12 ksiąg Roczników. Dopiero od tego momentu zanika rękopiśmienny sposób powielania tekstu tego dzieła. W Polsce edycja ta została przedrukowana dopiero w latach 1761-1777 przez warszawskiego wydawcę Mitzlera Wawrzyńca de Kolof ${ }^{4}$.

Dużo mniejsze zainteresowanie budziły wśród potomnych inne dzieła Długosza, ale i one były znane i czytane. Część z nich pozostała na długo w postaci rękopiśmiennej, przy czym stopień upowszechnienia ich tekstu był zróżnicowany. Najchętniej sięgano po prace heraldyczne, a zwłaszcza Insignia seu clenodia Regni Poloniae, które były często kopiowane i adaptowane, chociaż raczej nie zdawano sobie sprawy $\mathrm{z}$ tego, kto był ich autorem ${ }^{5}$. W autografie i nielicznych kopiach pozostał z kolei Liber beneficiorum dioecesis Cracoviensis, który służył głównie do użytku wewnętrznego krakowskiego Kościoła ${ }^{6}$. Dużo większym natomiast zainteresowaniem cieszyła się twórczość żywotopisarska i biograficzna Długosza ${ }^{7}$. Zwłaszcza Żywot św. Stanisława był chętnie drukowany w Polsce i za granicą, został on też jako pierwsze dzieło Długosza wydany w krakowskiej drukarni Hallera już w $1511 \mathrm{r}^{8}$

Zainteresowanie dziełami Długosza od połowy XVIII w. zaczyna nabierać dodatkowego charakteru, związanego z poszukiwaniem i opisem rękopiśmiennych i drukowanych przekazów piśmiennictwa polskiego. Już w 1732 r. Józef A. Załuski opublikował słynną pracę pt. Programma litterarium, w której sformułował potrzebę zebrania, ewidencji i ochrony dawnych ksiąg, a zwłaszcza źródeł do historii Polski. Jednocześnie ogłosił projekt wydawnictw katalogo-

4 O edycji dobromilskiej i lipskiej Roczników Długosza zob. P. Dymmel, W sprawie warsztatu edytorskiego dawnych wydań Roczników Jana Długosza, „Studia Historyczne”, R. 34, 1991, z. 3, s. $350-359$.

5 P. Dymmel, Problem autorstwa Klejnotów przypisywanych Janowi Dlugoszowi, „Rocznik Polskiego Towarzystwa Heraldycznego", t. 1 (12), 1993, s. 6o; tenże, Pierwsza redakcja najstarszego herbarza polskiego, [w:] Ludzie i herby w dawnej Polsce, red. P. Dymmel, Lublin 1995, s. 89-91.

6 O rękopisach Liber beneficiorum zob. S. Kuraś, Regestrum Ecclesiae Cracoviensis. Studium nad powstaniem tzw. Liber Beneficiorum Jana Długosza, Warszawa 1966, s. 5-10; M. D. Kowalski, Dzieje autografu katedralno-kolegiackiej części Liber beneficiorum dioecesis Cracoviensis Jana Długosza, „Studia Źródłoznawcze”, t. 46, 2009, s. 84-85.

7 Informacje o rękopisach Żywotu św. Stanisława i Żywotu bt. Kingi oraz katalogów biskupów polskich, będących świadectwem znajomości dzieł Długosza, najpełniej zestawił H. Zeissberg, Dziejopisarstwo polskie wieków średnich, t. 2, Warszawa 1977, s. 91-112.

8 Vita beatissimi Stanislai Cracouiensis episcopi..., Impressum Cracovie: in edibus (...) Joannis Haller, 1511. 
wych i bibliograficznych'. Realizacja tego programu zapoczątkowała badania nad utworami i autorami polskimi, w tym także nad osobą i pisarstwem Jana Długosza.

Najbardziej twórczym wykonawcą programu Załuskiego był Jan Daniel Janocki, od 1751 r. prefekt Biblioteki Załuskich. Z jego działalnością wiążą się też początki badań nad spuścizną Długosza. Nie miały one jednak specjalnie wyodrębnionego charakteru, mieściły się w całym polu zainteresowania dawnym piśmiennictwem polskim, zgodnie z kierunkiem nakreślonym w Programma litterarium. Janocki rękopisy dzieł Długosza opisał w trzech swoich pracach biobibliograficznych: Specimen catalogi codicum manuscriptorum Bibliothecae Zaluscianae, Musarum Sarmaticarum specimina nova i Janociana ${ }^{10}$. Szczególne znaczenie dla poznania twórczości Długosza miały Janociana. W tomie 2, który wyszedł jeszcze za życia Janockiego, została przekazana najpełniejsza wówczas wiedza o przechowywanych w zbiorach krajowych i zagranicznych rękopisach Annales $^{11}$. Pozostałe dzieła Długosza zostały opisane w t. 3, który niestety ukazał się dopiero 40 lat później, a jego druk zawdzięczamy Samuelowi Lindemu. Tutaj zostały wymienione pozostałe dzieła Długosza znane z zachowanych rękopisów. Należały do nich Żywoty św. Stanisława i bł. Kunegundy, katalogi arcybiskupów gnieźnieńskich, biskupów krakowskich, wrocławskich i płockich, dalej Liber beneficiorum i Banderia Prutenorum. Janocki za Maciejem z Miechowa wspomina też o przypisywanym Długoszowi herbarzu, ale nie może potwierdzić tej wiadomości odnalezionym rękopisem tego dzieła. Wymienia także 16 listów Długosza pisanych do różnych adresatów ${ }^{12}$.

Pod koniec XVIII wieku, dzięki inwentaryzacji rękopisów, znano już prawie pełną twórczość Długosza. Jeszcze u Janockiego wiedzę tę prezentowano w postaci katalogów rękopisów, w których starano się najlepiej jak wówczas umiano opisać rękopiśmienne przekazy zabytków polskiego piśmiennictwa, w tym oczywiście i Długosza. Z czasem jednak zainteresowanie dawnym pi-

9 Zob. P. Dymmel, Z dziejów kodykologii w Polsce. Dziewiętnastowieczne badania nad rękopisami Roczników Jana Długosza, [w:] Z badań nad polskimi księgozbiorami historycznymi, t. 14, Wyniki i perspektywy, red. nauk. B. Bieńkowska, Warszawa 1992, s. 7-8.

${ }_{10}$ J. D. Janocki, Specimen catalogi codicum manuscriptorum Bibliothecae Zaluscianae, Dresdae 1752; tenże, Musarum Sarmaticarum specimina nova, Vratislaviae 1771; tenże, Janociana, sive clarorum atque illustrium Poloniae auctorum maecenatumque memoriae miscellae, vol. 1-2, Varsaviae et Lipsiae 1776-1779; vol. 3, wyd. S. B. Linde, Varsaviae 1819.

11 Janociana, vol. 2, s. 68-78.

12 Janociana, vol. 3, s. 99-117. 
śmiennictwem zaczęło przybierać postać syntetycznych ujęć historii literatury polskiej, w których cechą charakterystyczną było występowanie elementów biograficznych i bibliograficznych. Odegrały one ważną rolę w kształtowaniu się bibliografii twórczości Długosza, którą wówczas po raz pierwszy zaczęto w sposób zamierzony potrzebami poznawczymi dokumentować także wydaniami drukowanymi jego dzieł. Taki charakter ma już opublikowana na początku XIX w. Historia literatury polskiej Feliksa Bentkowskiego. W drugim tomie, wydanym w 1814 r., podał on informacje o istniejących wówczas edycjach dzieł Długosza, wśród których znalazły się głównie edycje Annales ${ }^{13}$. W tym samym nurcie mieści się najwybitniejsza synteza literacka czasów romantyzmu, mianowicie $\mathrm{Hi}$ storia literatury polskiej Michała Wiszniewskiego. W tomie 4, opublikowanym w 1842 r., Wiszniewski wiele miejsca poświęca Długoszowi i jego twórczości, którą dokumentuje znanymi rękopisami, edycjami i tłumaczeniami. Dzięki tym przekazom zestawia najobszerniejszy katalog dzieł Długosza, obejmujący prawie pełną jego twórczość ${ }^{14}$. Zaliczył do niej też, w formie osobnego dzieła, istniejący ponoć tekst zatytułowany Chorografia Regni Poloniae, będący w rzeczywistości integralną częścią poprzedzającą Roczniki. Należy dodać, że Wiszniewski w t. 7 swej syntezy, opublikowanym w 1845 r., szeroko upowszechnił informację o odkryciu przez Aleksandra Batowskiego w Bibliotece Ossolińskich rękopisu, który okazał się bezpośrednim świadectwem herbarza Długosza, znanego dziś pod nazwą Insignia seu clenodia Regni Poloniae ${ }^{15}$. Odtąd Klejnoty staną się nieodłączną częścią dorobku pisarskiego Długosza.

W latach 40. XIX w. pojawił się nowy nurt zainteresowania i badań nad rękopiśmiennymi przekazami dzieł Jana Długosza, który silnie wspomagał tworzenie bibliografii podmiotowej tego autora. W odróżnieniu od wcześniejszych prac rękopisoznawczych i historyczno-literackich był on wyraźnie zorientowany na twórczość samego Długosza. Celem były poszukiwania, inwentaryzacja i opis wszystkich zachowanych w zbiorach polskich i obcych rękopisów jego dzieł.

${ }^{13}$ F. Bentkowski, Historya literatury polskiej, t. 2, Warszawa-Wilno 1814.

${ }_{14}$ M. Wiszniewski, Historia literatury polskiej, t. 4, Kraków 1842, s. 30 (Banderia Prutenorum), s. 64-71 (kronika), s. 64-71, 117-121 (edycja siedmiu listów Długosza), s. 83-98 (Żywot św. Stanisława, Żywot bł. Kingi, katalogi biskupów: gnieźnieńskich, wrocławskich i poznańskich, dzieło o herbach przypisywane Długoszowi), s. 110-111 (Liber beneficiorum).

15 Ibidem, t. 7, Kraków 1845, s. 505, przyp. 421. Trzy lata wcześniej M. Wiszniewski na podstawie kroniki Macieja z Miechowa przypisywał Długoszowi dzieło o herbach szlacheckich, jednak nie było ono wówczas jeszcze znane - ibidem, t. 4. O odkryciu i atrybucji Klejnotów Długosza zob. P. Dymmel, Problem autorstwa Klejnotów, s. 60. 
Zainteresowanie dziełami Długosza i związaną z nimi spuścizną rękopiśmienną jeszcze bardziej przybrało na sile, gdy pod koniec lat 50. XIX w. ogłoszono zamiar wydania dzieł wszystkich Długosza ${ }^{16}$.

W nurcie tych badań szczególne zainteresowanie budziły Roczniki, które były z jednej strony największym i najbardziej znanym dziełem Długosza, $\mathrm{z}$ drugiej posiadały bogatą tradycję rękopiśmienną. Tym niemniej w tym czasie zostały także rozpoznane i opisane inne rękopiśmienne przekazy jego dzieł. Systematyczne badania nad rękopisami dzieł Długosza rozpoczął Aleksander Batowski, który rozpoznał i opisał kodeksy znajdujące się w Bibliotece Zakładu Narodowego im. Ossolińskich we Lwowie ${ }^{17}$. Kilka lat później podobne prace podjął Józef Muczkowski, który zbadał i opisał rękopisy przechowywane w bibliotekach krakowskich ${ }^{18}$. Z kolei Antoni Białecki zajął się zbadaniem rękopisów dzieł Długosza przechowywanych w Petersburgu, dokąd trafiły bogate w dlugossiana zbiory Biblioteki Załuskich i Biblioteki Uniwersytetu Warszawskiego ${ }^{19}$. Szczególnie ważne znaczenie dla poznania spuścizny pisarskiej Długosza miały prace związane $\mathrm{z}$ edycją jego dzieł wszystkich, rozpoczęte pod patronatem hr. Aleksandra Przezdzieckiego. W ciągu dziesięciu lat udało się zebrać informacje o rękopisach jego dzieł przechowywanych w zbiorach publicznych, kościelnych i prywatnych na ziemiach polskich i za granicą. Informacje te były systematycznie publikowane przez Józefa Łepkowskiego i A. Przezdzieckiego na łamach „Biblioteki Warszawskiej”, przyczyniając się do propagowania wiedzy o życiu i dorobku Długosza ${ }^{20}$. Warto dodać, że J. Łepkowski jest autorem systematycz-

16 P. Dymmel, W sprawie warsztatu, s. 361-363.

17 A. Batowski, Rękopisma księgozbioru Ossolińskich. Rękopisma dziejów polskich przez Długosza, „Biblioteka Narodowego Zakładu im. Ossolinskich”, t. 5, 1843, s. 41-80; tenże, Niektóre rękopisma księgozbioru Zakładu Narodowego imienia Ossolińskich, Lwów 1844. Por. P. Dymmel, Z dziejów kodykologii, s. 15.

18 J. Muczkowski, Wiadomość o rękopismach Historyi Długosza, „Rocznik Towarzystwa Naukowego z Uniwersytetem Jagiellońskim złączonego”, 1850, z. 2, s. 169-247; tenże, Wiadomość o rękopismach Historyi Długosza, jego Banderia Prutenotum tudzież Insignia seu clenodia Regni Poloniae, Kraków 1851. Autor opisał rękopisy z bibliotek: uniwersyteckiej, kapituły krakowskiej, księży misjonarzy na Stradomiu i prywatnej Antoniego Z. Helcla. Por. P. Dymmel, Z dziejów kodykologii, s. 16, 21.

19 A. Białecki, Rękopisma Dtugosza w petersburskich bibliotekach pod względem paleograficznym i bibliograficznym, Petersburg 186o. W pracy autor opisał rękopisy z Cesarskiej Biblioteki Publicznej, Biblioteki Sztabu Generalnego i Biblioteki Rzymsko-Katolickiej Duchownej Akademii. Por. P. Dymmel, $Z$ dziejów kodykologii, s. 30-33.

${ }^{20}$ J. Łepkowski, Sprawozdanie z czynności wydawnictwa dzieł Długosza. I, „Biblioteka Warszawska”, t. 2, 1859, s. 854-863; tenże, Sprawozdanie z czynności wydawnictwa dzieł Długosza. II, „Biblioteka Warszawska”, t. 4, 1859, s. 782-787; tenże, Sprawozdanie z czynności wydawnictwa 
nego zestawienia przekazów rękopiśmiennych dzieł Długosza, wykorzystanych w ramach Opera omnia ${ }^{21}$. Z kolei A. Przezdziecki zebrał i opracował informacje o wszystkich znanych ówcześnie rękopisach Roczników ${ }^{22}$. Pełne podsumowanie poszukiwań i badań nad rękopisami dzieł Długosza przyniosła opublikowana w 1873 r. synteza średniowiecznego dziejopisarstwa polskiego Henryka Zeissberga $^{23}$. Jej autor skrupulatnie zebrał i uzupełnił informacje o rękopiśmiennych przekazach dlugossianów, dając solidną podstawę, w wielu miejscach do dziś niezastąpioną, do badań nad twórczością Długosza.

\section{Bibliografia narodowa}

Kolejny etap rejestracji twórczości Jana Długosza jest związany z powstaniem polskiej bibliografii narodowej zatytułowanej Bibliografia polska, której twórcami były trzy pokolenia Estreicherów. Zapoczątkował ją w 1870 r. Karol Estreicher, następnie była ona kontynuowana przez jego syna Stanisława i wnuka Karola ${ }^{24}$. Jak wiadomo składa się z czterech części, które obejmują piśmiennictwo polskie od początku drukarstwa aż do końca XIX wieku. Wszystkie te części są interesujące z punktu widzenia dzieł Długosza, przy czym najmniej praktyczna jest część II, obejmująca druki w układzie chronologicznym. Pozostałe trzy części, tj. I, III i IV zawierają opisy druków w układzie alfabetycznym według autorów lub tytułów. W przypadku autora, którego dorobek pisarski zaowocował większą liczbą druków zostały utworzone hasła osobowe, obejmujące wszystkie druki zebrane w danej części. Tak jest w przypadku Jana Długosza, który w części I, III i IV Bibliografii polskiej posiada własne hasło. Każda z tych części ukazywała się w innym czasie, ale ponieważ mają one charakter retrospektywny data

dzieł Dlugosza. III, „Biblioteka Warszawska”, t. 1, 1860, s. 742-756; A. Przezdziecki, Sprawozdanie z czynności wydawnictwa dzieł Długosza (IV), „Biblioteka Warszawska”, t. 1, 1865, s. 446-455; tenże, Piąte sprawozdanie z czynności wydawnictwa dzieł Długosza wraz z krótkim opisaniem po dziś dzień znanych 64 rękopisów, 6 ułamków i 10 streszczeń Historii polskiej Długosza, „Biblioteka Warszawska”, t. 2, 1870, s. 31-40.

${ }^{21}$ Joannis Dlugosii senioris canonici Cracoviensis opera omnia. Cura A. Przezdziecki, t. 1, Cracoviae 1887.

${ }^{22}$ A. Przezdziecki, Énumeration et déscription sommaire de 64 mss., 6 fragm. et 10 abrégés de l'Histoire de Pologne de Jean Dlugosz (dit Longin), Cracovie 1870.

${ }^{23}$ H. Zeissberg, Die polnische Geschichtschreibung des Mittelalters, Leipzig 1873; przekład polski: Dziejopisarstwo polskie wieków średnich, t. 2, Warszawa 1877, s. 88-193.

${ }^{24}$ M. Dembowska, Metoda „Bibliografii polskiej” Karola Estreichera, Warszawa 1970. 
publikacji poszczególnych tomów nie ma znaczenia dla określenia chronologii przedmiotowej.

W części III w tomie 4, opublikowanym w 1897 r., zostały zebrane i opisane najstarsze drukowane wydania dzieł Długosza, pochodzące z okresu od XVI do końca XVIII wieku. Z uwagi na brak jeszcze w tym okresie prac badawczych poświęconych Długoszowi faktycznie w tym tomie Bibliografii polskiej otrzymaliśmy nową wersję bibliografii podmiotowej. W sumie udało się Karolowi i Stanisławowi Estreicherom opisać 14 edycji i tłumaczeń dzieł Długosza wydanych w Polsce i za granicą ${ }^{25}$. Podobnie jak w przypadku innych autorów zarejestrowano je w układzie alfabetycznym według tytułów druków bez zważania na chronologię wydań i treść samego dzieła. Trzeba zaznaczyć, że opisy edycji zostały uzupełnione o dodatkowe informacje bibliograficzne i wydawnicze, $w$ tym dotyczące ich zawartości. W celu odróżnienia od głównego tekstu zostały podane petitem. $\mathrm{Na}$ końcu hasła został zamieszczony spis kilkudziesięciu pozycji, wymienionych z tytułu lub autora, w których znajdują się jakieś informacje o Długoszu lub które są jemu poświęcone. Do najstarszych należą prace Bernarda Wapowskiego, Marcina Kromera, Dawida Brauna i Jana D. Janockiego, natomiast najmłodsze sięgają czasu wydania Bibliografii, czyli końca lat 90. XIX stulecia ${ }^{26}$. Ten zapomniany już dzisiaj spis przedmiotowy ma wyjątkowe znaczenie, zasadniczo jako jedyny rejestruje w tak szerokim zakresie dawne piśmiennictwo o Długoszu. Nie powtarzają go ani późniejsze bibliografie historyczne, ani literackie, stąd do dziś zachowuje dużą wartość dokumentacyjną. W rezultacie nie udało się dla Długosza stworzyć bibliografii podmiotowej o przejrzystym układzie, najlepiej według jego dzieł.

Prawie trzy dziesięciolecia wcześniej od omawianego tomu, w 1870 r., ukazał się t. 1 Bibliografii polskiej, który w ogóle dał początek pomnikowemu dziełu Estreicherów. Rozpoczynał on ponadto część I obejmującą druki XIX stulecia od 1800 do 1880 roku. Znalazło się w nim w układzie alfabetycznym według tytułów osiem edycji dzieł Długosza w oryginale i tłumaczonych, opublikowanych w tym okresie. Wśród nich wielkością opisu wyróżniały się Opera omnia w wydaniu Aleksandra Przezdzieckiego, ale obok zostały wymienione inne dzieła Długosza: Insignia, Banderia Prutenorum, Katalog biskupów wrocławskich, a także po raz pierwszy tak bezpośrednio związane z twórczością Długosza Lites ac res gestae inter Polonos Ordinemque Cruciferorum w edycji Tytusa Działyńskiego ${ }^{27}$.

${ }^{25}$ K. Estreicher, Bibliografia polska, cz. III, t. 4, Kraków 1897, s. 243-247.

${ }^{26}$ Ibidem, s. 247.

${ }^{27}$ K. Estreicher, Bibliografia polska XIX stulecia, Kraków 1870, s. 318. 
Kontynuacją części I była część IV Bibliografii, zawierająca piśmiennictwo za ostatnich dwadzieścia lat XIX w., czyli od 1881 do 1900 r. Tom 1, który ukazał się w 1906 r., rejestruje tym razem nieliczne, bo zaledwie dwie, drukowane edycje dzieł Długosza oraz indeks do Historii polskiej wydanej w Opera omnia opracowany przez Teofila Żebrawskiego ${ }^{28}$. Podobnie jak w części III, w której znalazło się najwięcej opisów dzieł Długosza, tak również w obu częściach XIX-wiecznych nie zastosowano układu według utworów, co nadałoby poszczególnym hasłom osobowym czytelny charakter bibliografii podmiotowej. Na końcu haseł zostały zamieszczone odesłania do publikacji dotyczących Długosza, których opisy także znalazły się w odpowiednich częściach Bibliografii polskiej. W porównaniu z częścią III odniesienia bibliograficzne są jednak rzadsze i nie tworzą pełnego wykazu piśmiennictwa Długoszowego za dany okres.

Bibliografia Karola i Stanisława Estreicherów szybko stała się podstawowym źródłem wiedzy o dawnym piśmiennictwie polskim, do dorobku którego należała też twórczość Jana Długosza. Chociaż nie miała ona klasycznego charakteru przedmiotowego, dzięki systematycznej rejestracji druków faktycznie dawała możliwość stworzenia takiego spisu. Należy dodać, że jej obecność w świecie nauki i kultury ułatwiały dwa przedruki z lat 60. i 70. ubiegłego wieku. Pod koniec lat 50. z kolei została podjęta inicjatywa wydania reedycji bibliografii Estreichera dla druków z XIX w. Powstała ona z połączenia materiału części I i IV pierwszego wydania pod tytułem Bibliografia polska XIX stulecia. W t. 4, opublikowanym w 1966 r., znalazło się hasło poświęcone Długoszowi, które nie jest mechanicznym powtórzeniem zawartości wcześniejszego wydania ${ }^{29}$. W porównaniu z nim obejmuje 34 druki, czyli aż o 23 więcej. Różnica ta nie wypływa bynajmniej z jakiegoś szczególnego uzupełnienia stanu wiedzy o publikacje pominięte przez Karola i Stanisława Estreicherów. Takie uzupełnienia istotnie miały miejsce, ale były nieliczne i przeważnie niezwiązane bezpośrednio z twórczością Długosza. Karolowi Estreicherowi juniorowi udało się uzupełnić bibliografię tylko o edycję Banderiów wydaną przez Ernesta Strehlkego w serii Scriptores rerum Prussicarum. Pozostałe dodatki są okolicznościowymi drukami związanymi z czterechsetną rocznicą śmierci Długosza i prospektem wydania Opera omnia. Zasadniczy wpływ na wyraźnie większą liczbę opisów w Bibliografii polskiej

28 Tenże, Bibliografia polska XIX stulecia, lata 1881-1900, Kraków 1906, s. 312.

29 Tenże, Bibliografia polska XıX stulecia, red. K. Estreicher [jun.], t. 4, wyd. 2, Kraków 1966, s. $182-186$. 
XIX wieku miało rozpisanie właśnie Opera omnia na poszczególne tomy, które Karol Estreicher senior opisał w ramach jednej pozycji bibliograficznej.

Dziś tradycje bibliografii narodowej są kontynuowane w ramach nowego przedsięwzięcia bibliograficznego, podjętego przez Bibliotekę Narodową pod tytułem Bibliografia polska 1901-1939, której pierwszy tom ukazał się w 1986 r. ${ }^{30}$ W opublikowanym w 2002 r. tomie 5 zostało zamieszczone hasło poświęcone Janowi Długoszowi, jednak z uwagi na uwzględnianie w bibliografii tylko druków zwartych, znalazło się w nim zaledwie kilka prac wydanych w okresie czterech pierwszych dekad XX w. ${ }^{31}$ Nie może ona mieć zatem większego znaczenia w warsztacie badań nad Długoszem.

\section{Bibliografie historyczno-literackie}

Ważną rolę w kształtowaniu bibliograficznego obrazu dlugossianów mają bibliografie tworzone przez historyków literatury. Prace te wyrastają z wcześniejszego, romantycznego nurtu zainteresowań dziejami polskiego piśmiennictwa, który w ramach pozytywistycznego wzoru uprawiania nauki musiał zostać postawiony na mocnych fundamentach krytycznego warsztatu badań historyczno-literackich. Pierwszą bibliografią z tego zakresu jest Literatura polska Gabriela Korbuta, opublikowana dwukrotnie najpierw w latach 1917-1921 i następnie w wersji poszerzonej w latach 1929-1931 ${ }^{32}$. Dzięki przemyślanej konstrukcji oraz zakresowi zebranego materiału Literatura polska Korbuta była ważną pomocą informacyjną w studiach nad piśmiennictwem polskim. W obu wydaniach w t. 1 poświęconym piśmiennictwu staropolskiemu zamieszczone jest hasło dotyczące Jana Długosza (Johannes Longinus). Zbudowane jest według ogólnego schematu z następujących po sobie trzech segmentów: krótkiego biogramu Długosza, bibliografii podmiotowej, na którą składają się tytuły jego dzieł i bibliografii przedmiotowej, czyli wykazu piśmiennictwa jemu poświęconego ${ }^{33}$. W części podmiotowej znalazły się także informacje o edycjach i przekładach na język polski poszczególnych dzieł, a także o pracach opisujących przekazy rękopiśmienne. Z kolei w części przed-

30 Bibliografia polska 1901-1939, t. 1, A-Bars, red. J. Wilgat, red. tomu I. Olszewska, Warszawa 1986.

31 Ibidem, t. 5, Cz-Dn, oprac. I. Maziarz, Warszawa 2002.

32 G. Korbut, Literatura polska, t. 1-3, Warszawa 1917-1921; tenże, Literatura polska od początków do wojny światowej, t. 1-4, Warszawa 1929-1931.

33 Tenże, Literatura polska od początków, t. 1, s. 48-51. 
miotowej po raz pierwszy zebrano w jednym miejscu większość prac naukowych, opublikowanych do tego czasu w liczbie blisko 50 pozycji. Zostały one podane w porządku chronologicznym według czasu wydania. W wykazie tym znalazły się pojedyncze publikacje jeszcze z XVIII (Dawid Braun, De scriptorum Poloniae et Prussiae) i pierwszej połowy XIX w. (Łukasz Gołębiowski, O dziejopisach polskich; Richard Roeppel, Geschichte Polens), ale pozostałe pochodziły już z II połowy XIX i trzech pierwszych dekad XX wieku.

Po II wojnie światowej historycy literatury polskiej wyszli z inicjatywą opracowania nowej bibliografii, dla której wzorem miała być Bibliografia polska Korbuta. Już w 1950 r. został powołany Komitet Redakcyjny, na czele którego stanął Kazimierz Budzyk. Po czterech latach otrzymaliśmy pierwszą próbę jego działalności w postaci publikacji Bibliografia literatury polskiej okresu Odrodzenia, przygotowanej z okazji obchodzonego właśnie wtedy Roku Odrodzenia. Zostało w niej zamieszczone hasło Jan Długosz 1415-1480, dość obszerne, bo prawie dziesięciostronicowe ${ }^{34}$. Ogólna struktura haseł była wzorowana na Bibliografii Korbuta, ale można zauważyć istotne zmiany w ich proporcji, bowiem aż połowę zajmuje biogram Długosza pióra K. Budzyka, pozostała część została przeznaczona na bibliografię. Ta zachowała swój podmiotowo-przedmiotowy charakter z wyraźnym podziałem i osobnymi nazwami. Część podmiotowa zatytułowana Bibliografia wymienia wszystkie dzieła Długosza, podając przy tym czas ich powstania oraz opis drukowanych wydań. Dodatkowo wyróżnione w niej zostały publikacje podające wiadomości o rękopisach, wydania zbiorowe dzieł, edycje listów Długosza i dział „Autorstwo niepewne”, pod którym to tytułem umieszczono Vita Sbignei cardinalis z uwagą, że według Władysława Semkowicza i Fryderyka Papéego żywot ten nie jest dziełem Długosza ${ }^{35}$.

W części bibliograficznej pod osobnym tytułem „Opracowania” została zebrana literatura dlugossianów. Zastosowano dla niej układ chronologiczno-alfabetyczny, pierwszeństwo dając czasowi druku, a w przypadku publikacji wydanych w tym samym roku uporządkowano je według kolejności alfabetycznej ich autorów. Łącznie zebrano opisy ponad 120 prac, dzięki czemu powstała wówczas najobszerniejsza bibliografia Jana Długosza. Obejmowała ona głównie piśmiennictwo od połowy XIX w., ale za Korbutem powtórzono pozycje starsze:

${ }^{34}$ Bibliografia literatury polskiej okresu Odrodzenia (materiaty), oprac. K. Budzyk, R. Pollak, S. Stupkiewicz, Warszawa 1954, s. 61-70.

${ }^{35}$ Ibidem, s. 67, O żywotach Zbigniewa Oleśnickiego, zob. M. Koczerska, Piętnastowieczne biografie Zbigniewa Oleśnickiego, „Studia Źródłoznawcze”, t. 24, 1979, s. 5-82. 
Brauna, Gołębiowskiego i Roeppela uzupełnione o prace Hipolita Kownackiego. Najmłodsze prace pochodziły z lat 50. XX w., a zatem sięgały niemal do czasu wydania Bibliografii. Jej autorom udało się zebrać wszystkie podstawowe prace na temat Długosza, w tym obok polskich, także obce, które były pominięte przez Korbuta ${ }^{36}$. Zadbali też o w miarę systematyczne podawanie opisów recenzji odnoszących się do zamieszczonych prac. Ten zabieg znacznie pogłębił wartość informacyjną Bibliografii, ułatwiając śledzenie naukowej dyskusji o różnych aspektach życia, działalności i pisarstwa Długosza.

Bibliografia powstała jako próbny tom, który miał posłużyć za podstawę prac nad ostatecznym kształtem nowej bibliografii literatury polskiej. Dziewięć lat później ukazał się t. 1 Bibliografii literatury polskiej Nowy Korbut, która już swoim tytułem zapowiadała genetyczny związek z publikacją Gabriela Korbu$\mathrm{ta}^{37}$. Trzy pierwsze tomy zostały poświęcone piśmiennictwu staropolskiemu, w ramach którego znalazło się także hasło dotyczące Jana Długosza. Podobnie do wszystkich innych haseł osobowych zostało ono zbudowane według schematu zastosowanego już przez Korbuta i w Bibliografii z 1954 r., a więc z podziałem na trzy części: biograficzną, bibliografię podmiotową i bibliografię przedmiotową. Zrezygnowano z obszernych biogramów staropolskich autorów, poprzestając, podobnie jak to robił Korbut, na krótkich opisach zawierających podstawowe informacje o ich życiu i działalności. Uznano, że „jednym z podstawowych założeń nowego ujęcia jest ukazanie rozwoju twórczości pisarza i jego recepcji w społeczeństwie nie tyle przez odpowiednio opracowany życiorys, co przez podanie wszystkich jego utworów w chronologicznym porządku ich powstawania oraz ich wydań również w porządku chronologicznym"38. Teraz biogram Długosza zmieścił się na niecałej stronie książki, pozostałych osiem, a nawet dziewięć, wliczając uzupełnienie w t. 3 (Addenda), przeznaczono na właściwą partię bibliograficzną ${ }^{39}$.

${ }^{36}$ Zamieszczono m.in. prace: H. Sauerland, Eine Quelle der Historia Polonica des Johann Dlugosz (1378-1416), „Mitteilungen des Instituts für öesterreichische Geschichtsforschung”, t. 7, 1886, s. 642-647; M. Perlbach, Dlugosch's Quellen für die deutschen Geschichte in seinen ersten VI Büchern, „Neues Arch. der Gesellschaft für ältere Deutsche Geschichtskunde”, t. 14, 1889, s. 183-195 i E. Perfec'kyj, Peremyšl's' kij litopysnij kodeks peršoj redakciji v skladi chroniki Jana Dlugoša, „Zapysky Naukovoko Tovarystva imeni Ševčenka”, t. 147, 1927, s. 1-54; t. 149, 1928, s. 31-83.

${ }^{37}$ Bibliografia literatury polskiej Nowy Korbut, t. 1, Piśmiennictwo staropolskie, red. R. Pollak, Warszawa 1963.

${ }^{38}$ Ibidem, t. 1, s. 9.

${ }^{39}$ Bibliografia literatury polskiej Nowy Korbut, t. 2, Warszawa 1964, s. 127-136 i t. 3, Warszawa 1965 , s. $480-481$. 
Zgodnie z zapowiedzią w bibliografii podmiotowej w porządku chronologii powstawania dzieł zebrano całą twórczość Długosza, łącznie z jego listami. Poszczególne jednostki opisowe zawierają tytuł dzieła i czas jego powstania, po których zostały podane edycje i przekłady zarówno pełnego tekstu, jak i fragmentów. Wymieniono także tłumaczenia na języki nowożytne inne niż polski, wyróżniając ich opisy graficznie przez zastosowanie mniejszej czcionki. W bibliografii zebrano $\mathrm{w}$ jednym miejscu wszystkie znane edycje drukowane poszczególnych dzieł bez względu na czas wydania. Znalazły się tu więc i druki sprzed 1800 r., jak również wydania z XIX i XX w., tym samym potraktowano je na podobnej zasadzie, nie dokonując ich zróżnicowania $\mathrm{z}$ uwagi na metodę i warsztat edytorski. W bibliografii prezentującej twórczość Długosza w ślad za Bibliografia z 1954 r. w osobnych działach wyróżniono piśmiennictwo informujące o rękopisach jego dzieł, dalej wydania zbiorowe, listy i utwór o autorstwie niepewnym, za który słusznie uważano Vita Sbignei de Olesnica cardinalis.

Część przedmiotową w Nowym Korbucie w przypadku wszystkich haseł określono mianem „Opracowania” bez względu na formę piśmiennictwa, tak też oznaczono całą literaturę dotyczącą Długosza. Pochodzi ona z okresu, który, podobnie jak w dwóch wcześniejszych bibliografiach literackich, został wyznaczony za pomocą takich samych kryteriów. Początek sięga XVIII w. i został wyznaczony pracą Brauna, którą wciąż po 230 latach od ukazania się potraktowano jako ważne źródło wiedzy. Po raz pierwszy w bibliografiach długoszowych dodano też pracę Jana Daniela Janockiego pt. Janociana (vol. 2 i 3), w której, jak wiadomo, zostały opisane rękopisy i druki dzieł Długosza. Ostatnie odnotowane w Nowym Korbucie publikacje pochodzą z początku lat 60. ubiegłego wieku, a zatem sięgają niemal daty jej wydania, co nadawało bibliografii przedmiotowej wysoki status aktualności. Jej niezaprzeczalnym walorem był także zakres zebranego i opisanego piśmiennictwa.

Szerokiemu zakresowi chronologicznemu zebranego materiału towarzyszyły starania autorów Nowego Korbuta o uwzględnienie jak największej liczby publikacji związanych z Długoszem. Jest oczywiste, że z uwagi na charakter i przeznaczenie tej bibliografii koncentrowano się głównie na twórczości i osobie Długosza jako autorze licznych dzieł, ale nie pomijano prac związanych z jego szerszą działalnością, czy też kontekstem dziejowym. Uwzględniono również publikacje informacyjne i dotyczące tradycji długoszowskiej. Dodatkowego znaczenia nadało jej regularne odnotowywanie recenzji, co pozwoliło publikowane prace widzieć $\mathrm{w}$ ramach szerszej dyskusji naukowej. Dodać należy, że zgodnie z wypracowaną już wcześniej praktyką, w bibliografii zamieszczono zarówno prace polskie, jak i obce. 
Te wszystkie podstawowe zasady doboru materiału pozwoliły na stworzenie kompendium bibliograficznego o dużym stopniu kompletności i głębi informacyjnej. W sumie, nie licząc opisów recenzji, zebrano ok. 250 publikacji, a więc dwa razy więcej niż obejmowała wydana 10 lat wcześniej Bibliografia okresu Odrodzenia. W połowie lat 60 . XX w. był to największy publikowany wykaz piśmiennictwa poświęconego Długoszowi, wciąż aktualny i wykorzystywany.

W 1976 r. pod patronatem naukowym Instytutu Badań Literackich PAN podjęto prace nad nowym słownikiem pisarzy polskich, który miał przynieść najnowszy stan wiedzy biograficznej i bibliograficznej, w zamyśle autorów będący uzupełnieniem Nowego Korbuta. Długie i zawiłe losy tego wydawnictwa ostatecznie zaowocowały pięciotomową serią zatytułowaną Dawni pisarze polscy od początków piśmiennictwa do Młodej Polski. Przewodnik biograficzny i bibliograficzny, opublikowaną w latach 2000-2004. W t. 1 zostało zamieszczone hasło poświęcone Długoszowi, którego autorem jest znawca literatury średniowiecznej Tadeusz Witczak ${ }^{40}$. Praca ta została utrzymana w konwencji wydawnictwa dokumentacyjnego, łączącego biografię z bibliografią podmiotową i bibliografią przedmiotową. W odróżnieniu od Nowego Korbuta, który był przeznaczony głównie do prowadzenia kwerend i badań naukowych, Dawni pisarze polscy, w zamierzeniu twórców, mieli być podręcznym kompendium informacyjnym, adresowanym do szerokiego odbiorcy. Założenie to miało oczywiście swoje konsekwencje dla doboru haseł, chociaż pozycja Długosza była niezagrożona, w tym także, co nas tu głównie interesuje, dla konstrukcji hasła i doboru materiału. Szersze przeznaczenie słownika zadecydowało, że biogram z uwagi na mniej przygotowanego czytelnika jest obszerniejszy, a partie bibliograficzne z kolei, także z myślą o potrzebach tego czytelnika, są bardziej oszczędne w stosunku do Nowego Korbuta.

Bibliografia podmiotowa opatrzona tytułem „Twórczość” jest zasadniczo pełnym rejestrem utworów Długosza, nie zostały w niej zamieszczone tylko jego listy, rejestrowane w Nowym Korbucie. Autorzy Dawnych pisarzy polskich z zasady pomijali nieliterackie dziedziny piśmiennictwa zawodowego, a także utwory drobne, zaginione, niedokończone lub mniej ważne. Po raz pierwszy w bibliografii literackiej wyróżniono osobny dział „Praca redakcyjno-kolekcjonerska”, w którym odnotowano Lites ac res gestae inter Polonos Ordinemque Cruciferorum. W osobnych grupach wyróżniono także „Wydania zbiorowe”

40 Dawni pisarze polscy od początków piśmiennictwa do Młodej Polski. Przewodnik biograficzny i bibliograficzny, t. 1, A-H, Warszawa 2000, s. 227-233. 
i „Utwór o autorstwie niepewnym”, czyli Vita Sbignei. Prace Długosza, zgodnie z koncepcją przyjętą dla całego przewodnika, zostały uporządkowane chronologicznie. W opisie po tytule dzieła podawano, o ile posiadano takie wiadomości, czas powstania dzieła, pierwodruk, wydania krytyczne i przekłady polskie. W adnotacjach, zaznaczanych mniejszą czcionką, zamieszczano informacje o rękopisie autografu oraz przeróbkach i tłumaczeniach na inne języki nowożytne. Ważną nowością w stosunku do wcześniejszych bibliografii literackich jest zamieszczenie przy niektórych dziełach Długosza (Banderia Prutenorum, Annales, Liber beneficiorum, Lites ac res gestae) podstawowych informacji o ich zawartości, sposobie powstawania i znaczeniu. Rozwiązanie to także zostało wprowadzone z myślą o szerszym odbiorcy Dawnych pisarzy polskich.

W bibliografii przedmiotowej Długosza były rejestrowane głównie opracowania z zakresu piśmiennictwa, pominięto natomiast te dotyczące działalności niezwiązanej bezpośrednio z działalnością pisarską lub konkretnymi utworami. Ogólnym celem autorów przewodnika było ograniczenie się do opracowań najważniejszych i najnowszych, jednocześnie starano się pomijać prace zdeaktualizowane. W przypadku Długosza oznaczało to dość systematyczne uwzględnianie opracowań dopiero od lat 50. XX w., ze starszych wymieniono zaledwie pięć, na czele z biografią Długosza pióra Michała Bobrzyńskiego i Stanisława Smolki. Oprócz niej znalazły się prace Karola Potkańskiego o mitologii długoszowej, Jana Kornausa o Długoszu jako geografie, szeroko znany esej Ignacego Chrzanowskiego, przynoszący charakterystykę Długosza i biogram tegoż w Polskim słowniku biograficznym autorstwa Fryderyka Papéego. Zasięg chronologiczny zarówno biogramu, jak i bibliografii jest bliski wydania tomu 1, autorzy w sposób systematyczny rejestrowali prace do 1996 roku, tym niemniej uwzględniono też kilka prac z lat 1997-1998. Ostatecznie dzięki uzupełnieniom wprowadzonym w t. 5 Dawnych pisarzy polskich opublikowanym w 2004 r. zasięg chronologiczny piśmiennictwa sięga do $2002 \mathrm{r}^{41}$ Autorzy, odstępując od wypracowanej tradycji bibliograficznej, zapowiadali we wstępie, że rezygnują z podawania przy opisach prac recenzji. Na szczęście, wbrew tej zapowiedzi, w haśle długoszowym pojawiają się one nawet dość często, ale nie są zebrane w sposób systematyczny, co powoduje, że czytelnik w tym zakresie spotyka się z informacją niepełną i przypadkową. Recenzje odnotowano m.in. przy pracach S. M. Kuczyńskiego Spór o Grunwald (G. Labuda), S. Solickiego Źródła Jana Długosza do problematyki czeskiej (E. Zagajewska), K. Pieradzkiej Związki Długosza z Krakowem

${ }^{41}$ Ibidem, t. 5, Warszawa 2004, s. 249-250. 
(M. Bogucka), W. Szelińskiej Śląsk w piśmiennictwie Jana Długosza (D. Rott). Pominięto natomiast je dla innych prac, zarówno monografii, jak i edycji źródłowych.

Dość ostre kryteria doboru materiału spowodowały, że w tej bibliografii w części przedmiotowej, nie licząc recenzji, zamieszczono opisy tylko dla ok. 150 prac: w t. 1 ok. 130 i w t. 5 ok. 20. Należy dodać, że uzupełnienia bibliograficzne objęły także część podmiotową, ale były one nieliczne, dotyczyły tłumaczeń Vita beatae Cunegundis, fragmentów Liber beneficiorum i kolejnych tomów Roczników. Dzięki świeżej dacie wydania Dawni pisarze polscy są jak dotychczas najbardziej aktualnym spisem publikacji Długoszowych, zarejestrowanych w jednym miejscu. Koncentrując się na piśmiennictwie od lat 50. ubiegłego wieku stały się faktycznie kontynuacją Nowego Korbuta, który uzupełniają o prawie kolejnych 50 lat dorobku pisarskiego na polu badań nad Długoszem.

W grupie bibliografii historyczno-literackich wymienić też trzeba Polska bibliografię literacką, która ma charakter bieżący i obejmuje piśmiennictwo od lat 1944/1945. Jej pierwszy tom za 1948 r. ukazał się w 1954 r. ${ }^{42}$ Roczniki sięgające do 1988 r. były wydawane $\mathrm{w}$ formie drukowanej, kolejne były przygotowywane w formie elektronicznej. Dziś materiał za lata 1988-2002 jest dostępny on-line ${ }^{43}$. Polska bibliografia literacka obejmuje m.in. piśmiennictwo naukowe poświęcone historii literatury polskiej, poczynając od średniowiecza. Wśród dzieł i autorów średniowiecznych sukcesywnie odnotowywane jest piśmiennictwo poświęcone Janowi Długoszowi bez względu na rodzaj publikacji, a więc monografie i inne druki zwarte, artykuły, recenzje, sprawozdania. Z uwagi na charakter bibliografii preferowane są publikacje dotyczące twórczości pisarskiej Długosza, rzadziej jego życia i działalności. Wobec pojawienia się kompendium Dawni pisarze polscy praktyczne znaczenie tej bibliografii dziś nieco zmalało, ale niewątpliwie będzie ono wzrastać, gdy pojawią się w niej nowe publikacje wykraczające poza materiał opublikowany w wydanych już bibliografiach retrospektywnych. Nie bez znaczenia jest też zwiększająca się dostępność katalogu w Internecie, co ułatwia jej przeszukiwanie.

42 Polska bibliografia literacka za rok 1948, Wrocław 1954. Dopiero w 1957 r. ukazał się pierwszy tom bibliografii za lata 1944/45.

${ }^{43}$ Obecnie w wersji elektronicznej dostępnych jest ponad 100 rekordów z opisami publikacji dotyczących twórczości Długosza - http://www.pbl.ibl.poznan.pl/dostep/index.php?s=d_bieza cy\&f=zapisy\&p_tworcaid=1449, [dostęp 22.04.2017]. 


\section{Bibliografie historyczne}

W porównaniu $\mathrm{z}$ dorobkiem bibliograficznym historyków literatury znacznie słabiej rozwijał się w Polsce ruch wokół wydania bibliografii obejmującej piśmiennictwo dotyczące autorów i źródeł historycznych. Jednym z głównych powodów takiej sytuacji była wspólna tradycja piśmiennicza, do której odwoływali się zarówno historycy, jak i badacze literatury, zwłaszcza tej starszej - średniowiecznej i wczesnonowożytnej. Działo się to także wówczas, gdy ci ostatni niechętnie godzili się na poszerzanie pojęcia literatury o piśmiennictwo zgoła nieliterackie, nie mówiąc już o współczesnych nam czasach, w których to pojęcie obejmuje bardzo szeroki zakres form pisarskich. Jak już o tym powiedziano wyżej, w bibliografiach literackich chętnie umieszczano hasła związane $\mathrm{z}$ dawnymi autorami lub zabytkami pisarskimi, które mimo wszystko bardziej należą do świata historii niż literatury. W rezultacie bibliografie literackie zaspokajały w dużej mierze potrzeby bibliograficzne historyków i zwalniały ich z obowiązku opracowywania własnych kompendiów tego rodzaju. W księgozbiorach historycznych $\mathrm{z}$ reguły jest obecny Nowy Korbut, o nim też, jak również o Bibliografii polskiej Gabriela Korbuta spotkać można informacje w co bardziej ambitnych wprowadzeniach do studiów historycznych ${ }^{44}$. Dodać jednak trzeba, że historycy dobrze znają ograniczenia bibliografii literackich, skoncentrowanych głównie na pracach dotyczących twórczości, stąd dalekich od zebrania pełnego piśmiennictwa.

Przyczyną dość słabego zainteresowania polskich historyków tworzeniem pomocy bibliograficznych o źródłoznawczym charakterze może też być dorobek bibliograficzny w tym zakresie historiografii obcej. W historiografii niemieckiej i francuskiej już w XIX w. pojawiły się fundamentalne prace, które gromadziły piśmiennictwo o polskich autorach, w tym także dotyczące Jana Długosza. Podobnie jak bibliografie literackie, także te kompendia, dzięki swej stosunkowo łatwej dostępności, były dobrze znane i wykorzystywane przez historyków. Pierwszą pracą tego typu była Bibliotheca historica medii aevi Augusta Potthasta po raz pierwszy opublikowana w $1862 \mathrm{r}^{45}$ Uznano ją za najbardziej kompletny przewodnik, choć niewolny od błędów, po drukowanych edycjach źródeł do historii średniowiecznej Europy w okresie 400-1500. Jej pozycję ugruntowa-

${ }^{44}$ Por. B. Miśkiewicz, Wstęp do badań historycznych, wyd. 4, Warszawa 1985, s. 170.

${ }^{45}$ A. Potthast, Bibliotheca historica medii aevi. Wegweiser durch die Geschichtswerke des europäischen Mittelalters von 375-150o, Berlin 1862, s. 397; tenże, Bibliotheca historica medii aevi. Wegweiser durch die Geschichtswerke der europäischen Mittelalters von 375-1500: Supplement, Berlin 1868, s. 88. 
ło drugie wydanie poprawione i uzupełnione z $1896 \mathrm{r}$. Jego reprint ukazał się w $1957 \mathrm{r}^{46} \mathrm{~W}$ tomie 2 Biblioteki Potthasta znalazło się obszerne hasło poświęcone Długoszowi, nazywanego tu rozmyślnie, $\mathrm{z}$ uwagi na czytelnika niepolskiego, w łacińskiej formie Dlugossius seu Longinus. Bibliografia ma charakter podmiotowo-przedmiotowy jednak z wyraźną przewagą informacji o twórczości Długosza. Po raz pierwszy w literaturze naukowej zebrano w formie bibliograficznego repertorium całą twórczość Długosza. Trzeba wyjaśnić, że w głównym haśle poświęconym Długoszowi zestawiono wszystkie jego dzieła z wyjątkiem tych o tematyce hagiograficznej, czyli Żywotów św. Stanisława i bł. Kunegundy, które zostały opisane osobno pod tytułami tych dzieł. Za to dzięki edycji Wojciecha Kętrzyńskiego w Monumenta Poloniae Historica do dorobku pisarskiego Długosza włączono Articuli de incorporatione Masoviae. Zebrane dzieła zostały uporządkowane alfabetycznie w ramach kolejnych jednostek opisowych. Jednostka taka składa się z tytułu dzieła, informacji o rękopisach z odesłaniem do pracy Zeissberga o dziejopisarstwie polskim ${ }^{47}$, a przede wszystkim opisu edycji drukowanych. Starano się podać wszystkie znane wydania, co pozwoliło stworzyć także po raz pierwszy ich pełny zestaw. W jednostce opisowej znalazła się również literatura dotycząca rękopisów i wydań poszczególnych utworów Długosza.

Część przedmiotowa bibliografii Długosza jest raczej skromna, składa się zaledwie z niespełna 30 pozycji, co w żaden sposób nie oddaje ówczesnego stanu piśmiennictwa Długoszowego. Sytuacja ta była wynikiem przyjętej przez Potthasta koncepcji dzieła, która zmierzała do zebrania informacji głównie o twórczości średniowiecznych autorów. Ponadto w przypadku Długosza zamieszczono przeważnie prace niemieckojęzyczne, ale są też podstawowe publikacje polskie, takich autorów jak J. Muczkowski, A. Białecki, M. Bobrzyński i S. Smolka oraz J. Łepkowski, Józef Szujski i Bolesław Ulanowski. Dla potrzeb obcego odbiorcy polskie tytuły zostały przetłumaczone na niemiecki.

Bibliotheca Augusta Potthasta dobrze odpowiadała na oczekiwania pozytywistycznej historiografii. Historycy zdawali sobie sprawę z potrzeby tworzenia pomocy warsztatowych i informacyjnych, które będą podstawą i narzędziem krytycznych studiów. Zapewne z tych samych przesłanek wyrosło analogiczne do Potthasta i bliskie mu czasowo kompendium bibliograficzne powstałe na gruncie historiografii francuskiej. W latach 1877-1886 ukazała się pierwsza część

46 A. Potthast, Bibliotheca historica medii aevi. Wegweiser durch die Geschichtswerke des europäischen Mittelalters bis 1500. Bd. 1-2, wyd. 2, Berlin 1896. Reprint tego wydania: Graz 1957.

47 H. Zeissberg, op. cit. 
dwutomowego dzieła Ulyssesa Chevaliera zatytułowanego Répertoire des sources historiques du moyen âge ${ }^{48}$. Część ta nosiła podtytuł „Biobibliographie”, który wyraźnie wskazywał na jej zawartość, złożoną z haseł autorów i dzieł średniowiecznych. Repertorium to od razu stało się jednym z najważniejszych bibliograficznych przewodników do studiów mediewistycznych zawierających, jak to określiła Encyclopaedia Britannica "an enormous mass of useful information”, chociaż, co trzeba wyraźnie zaznaczyć, nie zawsze wartościowych. O jego powodzeniu zadecydowało też drugie wydanie z lat 1905-1907, którego reprint ukazał się w 1959 r. ${ }^{49} \mathrm{~W}$ odróżnieniu od Potthasta Répertoire Chevaliera było w zasadzie bibliografią przedmiotową, stąd w haśle poświęconym Długoszowi zestawiono tylko piśmiennictwo jemu poświęcone. Liczbą pozycji jest ono podobne do dzieła niemieckiego bibliografa, obejmuje ok. 30 prac w układzie alfabetycznym. Większość $\mathrm{z}$ nich znana jest już z Potthasta, z nowych odnotowano Bibliografię polska Estreichera i studium Antoniego Prochaski Dlugosz o Elżbiecie, trzeciej żonie Jagiełly. Tytuły polskie zostały dodatkowo przetłumaczone na język francuski.

Wciąż postępujący rozwój badań nad autorami średniowiecznymi, w tym także nad Długoszem, spowodował, że nawet najlepsze kompendia i repertoria bibliograficzne stawały się niewystarczające, gdyż nie obejmowały piśmiennictwa opublikowanego po dacie ich wydania. W przypadku Długosza postęp studiów prowadzonych zarówno przez badaczy polskich, jak i z innych krajów dość szybko zdeaktualizował bibliografie przedmiotowe Potthasta i Chevaliera, które i tak były dalekie od kompletności. Zjawisko to występowało oczywiście w szerszej skali, stąd też już w latach 50. XX w. zrodziła się międzynarodowa inicjatywa opracowania na wzór Biblioteki Potthasta nowego dzieła bibliograficznego ${ }^{50}$. W pracach nad Nowym Potthastem, jak zaczęto nazywać to dzieło, uczestniczyli ze strony Polski Aleksander Gieysztor, Brygida Kürbisówna, Gerard Labuda i Ryszard Walczak. W 1962 r. ukazał się t. 1 tego dzieła pod tytułem Repertorium fontium historiae medii aevi primum ab Augusto Potthast digestum, nunc cura

${ }^{48}$ U. Chevalier, Répertoire des sources historiques du Moyen Age, t. 1, Bio-bibliographie, Paris 1877-1883, szp. 581: Dlugosz, Longinus (Jean).

49 U. Chevalier, Répertoire des sources historiques du Moyen Age, t. 1, A-I, Paris 1905, szp. 1204: Dlugosz, Longinus (Jean). Reprint tego wydania: New York 1959.

${ }^{50} \mathrm{Na}$ temat projektu Nowego Potthasta zob. A. Gieysztor, Prace nad reedycją bibliografii źródeł średniowiecznych (Bibliotheca historica medii aevi) Potthasta, „Studia Źródłoznawcze”, t. 1, 1957, s. 324-326. O postępach prac nad repertorium na bieżąco informowali A. Gieysztor („Studia Źródłoznawcze", t. 3, 1958, s. 330; t. 4, 1959, s. 226-227; t. 5, 196o, s. 203; t. 20, 1976, s. 283-284) oraz A. Gieysztor i B. Kürbisówna (ibidem, t. 9, 1964, s. 231; t. 13, 1968, s. 235). 
college historicorum e pluribus nationibus emendatum et auctum wprost nawiązujący do swego wielkiego poprzednika.

Hasło poświęcone Długoszowi znajduje się w t. 4 opublikowanym w 1976 r. ${ }^{51}$ Należy ono do jednych z obszerniejszych, znajduje się na 13 stronach i zajmuje 25 szpalt druku. Nowy Potthast jest repertorium bibliograficznym podmiotowo-przedmiotowym, które w sposób zrównoważony opisuje twórczość średniowiecznych autorów i dostarcza informacji o piśmiennictwie naukowym na ich temat. $\mathrm{W}$ porównaniu $\mathrm{z}$ dawnym Potthastem wyraźnemu poszerzeniu uległy partie bibliografii przedmiotowej. Inaczej niż we wszystkich wymienionych pracach bibliograficznych nie znajdziemy jej w całości w jednym miejscu hasła, lecz w różnych jego częściach. Zgodnie z ogólną koncepcją hasło poświęcone Długoszowi składa się z poszczególnych jednostek przeznaczonych do opisu konkretnego dzieła. Jednostkom tym nadano porządek alfabetyczny według łacińskich tytułów dzieł Długosza. Ich listę rozpoczynają Annales, po których następują kolejno: Articuli de incorporatione Masoviae, Banderia Prutenorum, Epistolae, Insignia seu clenodia regni Poloniae, Liber beneficiorum, Oratio habita coram Rmo d. Cardinali Crac., Vita beatae Kunegundis, Vita s. Stanislai i Vitae episcoporum Poloniae. Na uwagę zasługuje włączenie do dzieł Długosza mowy wygłoszonej z okazji przywiezienia kapelusza kardynalskiego dla biskupa Oleśnickiego. W ramach poszczególnej jednostki po tytule znajduje się krótki opis genezy i zawartości dzieła. Po nim następują wyróżnione osobnymi tytułami opisy bibliograficzne dotyczące: zbiorów rękopisów, wydań faksymilowych, edycji drukowanych i tłumaczeń. Jednostkę kończy bibliografia przedmiotowa złożona z publikacji odnoszących się tylko do danego dzieła. $Z$ takich powtarzalnych elementów składa się każda jednostka poświęcona konkretnemu dziełu. Na końcu hasła dodana jest jeszcze bibliografia ogólna, która obejmuje piśmiennictwo dotyczące ogólniejszych zagadnień źródłoznawczych, życia Długosza i jego różnych obszarów działalności. Spisy publikacji, zarówno w obrębie poszczególnych jednostek, jak i załączony na końcu hasła mają układ chronologiczny według roku wydania, co pozwala śledzić postęp naukowy i wydawniczy. Zarejestrowana w haśle poświęconym Długoszowi literatura obejmuje długi okres, pochodzi jeszcze z XVIII i początku XIX w.

${ }^{51}$ Repertorium fontium historiae medii aevii, primum ab Augusto Potthast digestum, nunc cura collegii historicorum e pluribus nationibus emendatum et auctum, t. 4, Romae 1976, s. 214226, bibliografia podmiotowo-przedmiotowa pod hasłem Długosz, Ioannes. Z Długoszem jest także związane hasło dotyczące Filipa Buonaccorsiego (Kallimacha), któremu przypisano autorstwo Vita Joannis Długosch - ibidem, t. 2, Fontes A-B, Romae 1967, s. 603-606, bibliografia podmiotowo-przedmiotowa: Buonaccorsi, Filippo. 
(G. Braun, Ł. Gołębiowski) i sięga aż do początku lat 70. XX w. Czas ten jeszcze bardziej się wydłuża w przypadku edycji dzieł, ponieważ w haśle zostały podane opisy wszystkich wydań, łącznie z tymi z okresu XVI-XVIII wieku, które z reguły uważa się za mało krytyczne.

W warsztacie bibliograficznym do badań nad Janem Długoszem przez długi czas istotne miejsce zajmowały dwie bibliografie retrospektywne dotyczące historii Polski. Pierwszą była trzytomowa Bibliografia historii Polski opracowana przez Ludwika Finkla i opublikowana w latach 1891-1906 ${ }^{52}$. Zawiera ponad sto pozycji dotyczących Długosza, opublikowanych do czasu wydania poszczególnych tomów. Nie prowadzono selekcji prac, starano się raczej odnotowywać wszystkie publikacje, nawet te drobne i o prasowym charakterze, co zarówno wtedy, jak i dziś ma swoją, trudną do powtórzenia, wartość poznawczą. Opisy dlugossianów znajdują się we wszystkich trzech tomach i są rozrzucone, bowiem w żadnym z nich nie ma osobnego hasła poświęconego Długoszowi. Jedynie w pierwszym tomie gromadzącym piśmiennictwo o źródłach, zebrano w jednym miejscu grupę ponad 50 publikacji. Warto dodać, że o miejscu i znaczeniu bibliografii Finkla w warsztacie badań historycznych świadczą prace nad jej reedycją ${ }^{53} \mathrm{i}$ wydanie anastatyczne $\mathrm{z}$ lat $1955-1956 \mathrm{r}^{54}$

Drugą bibliografią retrospektywną, gromadzącą w większym zakresie piśmiennictwo dotyczące Jana Długosza, jest Bibliografia historii Polski opublikowana pod redakcją Heleny Madurowicz-Urbańskiej w 1965 r. ${ }^{55} \mathrm{Z}$ uwagi na swój ogólny charakter nie zawiera osobnego hasła poświęconego Długoszowi, interesujące nas piśmiennictwo zostało ujęte w różnych miejscach w obrębie działów tematycznych. Łącznie obejmuje ona tylko 60 pozycji bibliograficznych dotyczących Długosza, opublikowanych w XX w. do połowy lat 60. Zamiarem autorów było zgromadzenie wybranych, najbardziej wartościowych publikacji, zarówno o życiu i działalności Długosza, jak i jego dziełach. Podobnie jak Bibliografia Finkla ma ona dziś coraz mniejsze znaczenie z uwagi na obecność nowszych bibliografii retrospektywnych o specjalnym charakterze, obejmujących twórczość autorów średniowiecznych.

${ }^{52}$ L. Finkel, Bibliografia historii Polski, cz. 1, Lwów 1891, cz. 2-3, Kraków 1895-1906. O Bibliografii i jej autorze zob. A. Nowak, Złote lata bibliografii polskiej. Ludwik Finkel i jego dzieło, Warszawa 2007.

${ }^{53}$ Zob. A. Nowak, op. cit., s. 145-169.

${ }^{54}$ L. Finkel, Bibliografia historii Polski, cz. 1-3, Warszawa 1955-1956.

55 Bibliografia historii Polski, t. 1 do roku 1795, cz. 1, red. H. Madurowicz-Urbańska, Warszawa 1965 . 
W grupie dzieł bibliograficznych dotyczących historii Polski nie można pominąć bibliografii bieżącej, wydawanej cyklicznie za dany rok. W środowisku historyków nosi ona nazwę Bibliografii Baumgarta, od nazwiska Jana Baumgarta, który rozpoczął jej publikację w 1952 r. pierwszym tomem za $1948 \mathrm{r}^{56}$ Wydane w następnych latach tomy pozwoliły objąć nią także piśmiennictwo wcześniejsze, poczynając od 1935 r. z wyłączeniem okresu II wojny światowej. Bibliografia ta jest wydawana do dziś, ostatni opublikowany w 2016 r. tom objął piśmiennictwo za 2014 r. Nie zawiera ona osobnego hasła poświęconego Długoszowi, prace o nim znajdują się w różnych miejscach w obrębie właściwych działów tematycznych, a dotarcie do nich jest możliwe dzięki indeksom. Bibliografia Baumgarta zyskuje na znaczeniu dzięki swej aktualności, czego nie mogą zapewnić bibliografie retrospektywne, ale dodatkowym atutem jest jej dostępność $\mathrm{w}$ formie elektronicznego katalogu w Internecie. Dotychczas zostały w nim zamieszczone tomy za lata 1980-2011, natomiast wbudowany mechanizm pozwala na wygodne przeszukiwanie rekordów przy zastosowaniu różnych kryteriów ${ }^{57}$. W dostępnym obecnie katalogu on-line znajduje się ponad 300 opisów publikacji dotyczących Długosza.

Należy zauważyć, że publikacje dotyczące życia i twórczości Jana Długosza mogą się także znaleźć w różnych opracowaniach bibliograficznych o przedmiotowym i specjalnym charakterze. Warto po nie sięgać, zwłaszcza wtedy, gdy interesuje nas określona tematyka związana z Długoszem. Przykładem mogą być wydane ostatnio dwie bibliografie edytorskie, gromadzące piśmiennictwo poświęcone edycjom i pracom wydawniczym, w tym także w związku z dziełami Długosza ${ }^{58}$. Zwrócić też trzeba tu uwagę na bibliografie grunwaldzkie, które $\mathrm{w}$ ramach gromadzenia publikacji związanych $\mathrm{z}$ bitwą pod Grunwaldem zawierają także liczne dlugossiana ${ }^{59}$.

${ }^{56}$ Bibliografia historii polskiej za rok 1948, oprac. J. Baumgart, Kraków 1952.

57 Wersja elektroniczna Bibliografii historii polskiej została opracowana we współpracy Instytutu Historii PAN z Instytutem Pamięci Narodowej. Zawiera te same dane, które znajdują się w kolejnych rocznikach Bibliografii wydawanych w formie drukowanej - http://www.bibliogra fia.ipn.gov.pl/bhp/katalog-on-line/8338,Katalog.html, [dostęp 22.04.2017].

${ }_{58}$ Zob. P. Chojnacki, R. Jaworski, J. Kaliszuk, P. Węcowski, Bibliografia źródeł drukowanych do dziejów Polski późnośredniowiecznej (1383-1506), cz. 1, Warszawa 1999; P. Dymmel, Bibliografia edytorstwa źródeł historycznych w Polsce. Historia - krytyka tekstu - metodyka i technika wydawnicza, Lublin 2001.

${ }^{59}$ Należy tu zwrócić szczególną uwagę na ostatnio wydane bibliografie wykorzystujące wcześniejsze opracowania: W. Mierzwa, Bibliografia grunwaldzka, Olsztyn 1990; H. Baranowski, I. Czarciński, Bibliografia bitwy pod Grunwaldem i jej tradycji, red. M. Biskup, Toruń 1990; 
Dotychczasowe osiągnięcia bibliograficzne zamyka opublikowany w 2016 r. artykuł Zbigniewa Stańczyka, pracownika Biblioteki Publicznej w Częstochowie, który zawiera wykaz piśmiennictwa poświęconego Długoszowi, będący w zamyśle i z nazwy bibliografią podmiotowo-przedmiotową ${ }^{60}$. Powstał on w związku z obchodzoną w 2015 r. sześćsetną rocznicą śmierci historyka i jest wyrazem pamięci i hołdu lokalnego środowiska naukowego odwołującego się do związków Długosza z ziemią częstochowską. W części podmiotowej opisano w układzie chronologicznym ponad 80 druków i edycji dzieł Długosza, poczynając od najstarszego druku - Żywotu św. Stanisława z 1511 r., a kończąc na opisach bitwy grunwaldzkiej wyjętych z Roczników, opublikowanych w 2010 r. Część przedmiotowa zawiera niewiele ponad 300 publikacji ułożonych alfabetycznie według autorów. Łącznie bibliografia obejmuje 390 pozycji, co stanowi mniej niż 20 proc. całej szacowanej liczby publikacji i z tego względu ma raczej charakter materiałów do bibliografii, a nie skończonego dzieła tego typu. Trudno też mówić o jej selektywnym charakterze przeprowadzonym zgodnie z przyjętymi założeniami metodycznymi, rejestruje ona bowiem dość przypadkowo piśmiennictwo znane autorowi $\mathrm{z}$ autopsji lub pozyskane $\mathrm{z}$ innych źródeł. Jej zaletą jest natomiast zamieszczenie publikacji wydanych w ciągu ostatnich dwóch dekad, co czyni z niej najbardziej aktualne, choć dalekie od kompletności, zestawienie ${ }^{61}$.

Podsumowując dotychczasowy przegląd pomocy bibliograficznych w warsztacie badań nad Janem Długoszem należy zwrócić uwagę na długą tradycję prac nad nimi, sięgającą początków syntez biobibliograficznych tworzonych w XVIII i pierwszej połowie XIX stulecia. Później zainteresowanie Długoszem było częścią prac nad bibliografią narodową oraz towarzyszyło w sposób naturalny po-

\footnotetext{
M. M. Hrynkiewicz, Bibliografia grunwaldzka za lata 1990-2009, „Komunikaty Mazursko-Warmińskie", 2010, nr 3, s. 373-409.

${ }^{60}$ Z. Stańczyk, Jan Długosz. Bibliografia podmiotowo-przedmiotowa, „Ziemia Częstochowska”, t. 43,2017 , s. 87-123.

${ }^{61}$ Interesujące, że w 2015 r. - w roku jubileuszu Jana Długosza - wiele publicznych bibliotek podjęło akcję przygotowania i opublikowania w Internecie bibliografii podmiotowo-przedmiotowych, które faktycznie są skromnym wyborem poświęconego mu piśmiennictwa przechowywanego we własnych zbiorach, np. Biblioteka Pedagogiczna w Chełmie, Publiczna Biblioteka Pedagogiczna w Koninie (http://www.cdnkonin.pl/pbp/images/Dlugosz_Jan.pdf, [dostęp 20.11.2018]), Publiczna Biblioteka Pedagogiczna w Poznaniu (http://www.pbp.poznan.pl/node/2041, [dostęp 20.11.2018]), Biblioteka Publiczna w Sieradzu (http://www.bpsieradz.pl/zestawienia/Dlugosz\%20 Jan.pdf, [dostęp 20.11.2018]). Mimo wszystko są one pożyteczne dla propagowania wiedzy o Janie Długoszu wśród uczniów i w lokalnych społecznościach.
} 
czątkom polskiej bibliografii historycznej i historyczno-literackiej. Ważne znaczenie w recepcji piśmiennictwa Długoszowego miały bibliografie obce, powstałe w drugiej połowie XIX w. Z kolei od końca XIX i początku XX w. zarysowują się dwa wyraźne obszary tworzenia bibliografii Długoszowej w rodzimej nauce. Jeden jest związany $\mathrm{z}$ badaniami historyków literatury nad piśmiennictwem średniowiecznym, drugi należy do zakresu badań historycznych, w którym życie, działalność i dzieła Długosza są częstym przedmiotem zainteresowania badaczy różnych specjalności. Obszar prac bibliograficznych z czasem uzupełniły kompendia dziedzinowe i specjalne.

Dorobek w zakresie bibliografii dotyczących Długosza, pomimo pewnych braków, należy ocenić pozytywnie. Obejmują one pełny zasięg chronologiczny dla piśmiennictwa naukowego, sięgając do jego początków umownie datowanych na połowę XIX w., a w wielu przypadkach dostarczają informacji także o starszych publikacjach. Z drugiej strony bibliografie bieżące dają możliwość śledzenia aktualnej produkcji wydawniczej, praktycznie już po dwóch latach od druku. Stopień selekcji piśmiennictwa jest zróżnicowany dla poszczególnych bibliografii, jest on większy w przypadku bibliografii ogólnych, zarówno historycznych, jak i literackich, ale wyraźnie się zmniejsza dla bibliografii przedmiotowych i specjalnych. Żadna z bibliografii nie przynosi kompletnego wykazu literatury Długoszowej, najbardziej obszerne są publikacje, których przedmiotem jest dawne piśmiennictwo. Stąd rodzi się potrzeba komplementarnego traktowania dostępnych repertoriów bibliograficznych, oczywistej w przypadku ich różnego zakresu chronologicznego i wymaganej z uwagi na preferencje rzeczowe występujące głównie między bibliografiami historyczno-literackimi a historycznymi.

Ten ogólny obraz stanu warsztatu bibliograficznego posiada też pewne niedostatki, o których warto tu powiedzieć. Przede wszystkim odczuwa się brak bibliografii przedmiotowej uwzględniającej całość piśmiennictwa dotyczącego Jana Długosza, we wszystkich aspektach jego życia, działalności i twórczości ${ }^{62}$. Trzeba też zauważyć, że poza głównym obiegiem bibliograficznym znajduje się piśmiennictwo popularyzatorskie i publicystyczne, które w wielu przypadkach

${ }^{62}$ Warto zauważyć, że w podobnej do Długosza sytuacji bibliograficznej są wszyscy inni polscy autorzy średniowieczni. W jakimś sensie wyjątkiem jest Wincenty Kadłubek, który ostatnio doczekał się wykazu poświęconych mu prac, opublikowanych od pierwszych wydawnictw nawet sprzed 1800 r. aż do 2009 r. Spis ten obejmuje blisko dwa tysiące pozycji i jest ułożony chronologicznie, ma charakter materiałów do przyszłej bibliografii - zob. Vincentiana. Materiały do bibliografii, zestawił K. Kollinger, [w:] Onus Athlanteum. Studia nad Kronika biskupa Wincentego, red. A. Dąbrówka, W. Wojtowicz, Warszawa 2009, s. 476-527. 
posiada autentyczną wartość poznawczą, a ponadto jest świadectwem szerszej kultury historycznej, egzemplifikowanej w tym przypadku zainteresowaniem osobą Długosza. Wyraźnym mankamentem obecnego stanu warsztatu bibliograficznego jest także rozproszenie źródeł informacji o piśmiennictwie dotyczącym Długosza. W konsekwencji wymaga to najpierw ich poznania, a w dalszej kolejności komplementarnego traktowania, o czym była już wyżej mowa.

Dotychczasowe rozważania prowadzą do oczywistego postulatu stworzenia osobnej bibliografii podmiotowo-przedmiotowej obejmującej całość piśmiennictwa dotyczącego Jana Długosza. Do realizacji tego celu konieczne jest dziś wykorzystanie narzędzi elektronicznych, które mogą być także pierwszym etapem prowadzącym do jej wydania w postaci drukowanej, o ile będzie taka potrzeba. Coraz częściej tradycyjny warsztat bibliograficzny współistnieje z, lub jest wprost zastępowany, bazami danych, katalogami elektronicznymi i aplikacjami internetowymi, które przyspieszają i ułatwiają tworzenie repozytoriów bibliograficznych oraz czynią je coraz bardziej dostępnymi. Niezależnie od wszystkich innych zalet aplikacja elektroniczna, w odróżnieniu od bibliografii drukowanej, daje możliwość aktualizowania danych, zarówno wstecz, gdy opisy wydanych prac zostały pominięte, jak i na bieżąco, gdy przybywają nowe publikacje. Bibliografia w postaci elektronicznej może być tworzona jako projekt otwarty bez wyznaczania jego terminu zakończenia. Podobną zaletę ma możliwość dokonywania weryfikacji błędnych i uzupełniania niepełnych opisów bibliograficznych. Przykładami wykorzystania technologii i techniki cyfrowej są dwie, wymienione w powyższym przeglądzie, bibliografie bieżące. Chodzi o Polską bibliografię literacka, dziś tworzoną wyłącznie w formie elektronicznej, i Bibliografię historii polskiej, wydawaną w postaci drukowanej i częściowo przeniesionej do elektronicznego katalogu. Obie te bibliografie dostępne są on-line.

W postaci internetowej aplikacji powinna być także tworzona nowa bibliografia podmiotowo-przedmiotowa Jana Długosza. Dziś można już założyć podstawowe wymagania informatyczne dla stworzenia takiej aplikacji. Wykorzystanie odpowiednich programów i języków programowania pozwoli na dostęp on-line do bazy, zarówno na etapie jej budowy, jak i korzystania z zawartości. Wszystkie dane wprowadzane do aplikacji będą zapisywane centralnie na serwerze, co zabezpieczy je przed utratą lub nieautoryzowanym dostępem. Baza wyposażona w mechanizm kont użytkownika umożliwi jednoczesne wprowadzanie dużej liczby opisów przez różnych użytkowników. Zaimplementowany do bazy mechanizm eksportu danych do różnych formatów pozwoli na ich przenoszenie do innych systemów lub przygotowywanie dodatkowych zestawień w oparciu 
o wyeksportowane dane. W końcu należy przewidzieć możliwość rozbudowy aplikacji o nowe funkcjonalności. Do skonstruowanej według tych założeń bazy danych można wprowadzić całe dotychczasowe piśmiennictwo dotyczące Długosza, bez względu na czas druku, rodzaj piśmiennictwa, formę wydawniczą i tematykę publikacji. Mechanizm wyszukiwawczy przy zastosowaniu odpowiednich filtrów będzie dawał możliwość pobierania z niej żądanych informacji.

Bibliografia podmiotowo-przedmiotowa w wersji elektronicznej dotycząca osoby i twórczości Jana Długosza jest projektem prywatnym przygotowywanym przez autora. Jej publikacja jest przewidziana w 2019 r.

\section{Summary}

\section{The Life and Works of Jan Długosz Described in Bibliographies}

The subject of the paper is the survey of primary sources (bibliographies of his works) and subject bibliographies connected with the person of Jan Długosz. The study will focus on four issues associated with the beginnings and development of these bibliographies, their kinds and content, and their role and significance in studies on Długosz. The author discusses four areas of bibliographic production related to Długosz. The first began in the $18^{\text {th }}$ century and was characterized by the publication of bio-bibliographic works, which combined biographical interests with the search for manuscript texts of his works. In the 1870s the second area emerged connected with the creation of the national bibliography of Polish literature. An important section of this literature was the printed editions of the works by Długosz, and subsequently, also publications devoted to him. This discussion will lead us to the answer to the question about the need and possibility of creating a modern and complete bibliographic compendium associated with this medieval historian. From the early $20^{\text {th }}$ century, the person of Długosz found its way into bibliographies compiled by literary historians, who first of all recorded the scientific achievements related to the studies on his works. Even earlier, from the 1860s, the fourth area developed in which many historical bibliographies were written. The person of Długosz first appeared in the wellknown foreign bibliographies - the German one by Potthast and the French one by Chevalier, later to become a permanent part of Polish bibliographic production created in different forms by Polish historians until today. Although there are many bibliographies, none of them provides a complete list of literature on 
Długosz, which is why they have to be used in a complementary way. The author suggests that a new bibliography be compiled which would combine primary sources and subject bibliography, and comprise the whole body of literature on Jan Długosz, in an electronic form as an Internet application. He says it will be published in 2019.

KEYWORDS: bibliography, Jan Długosz, $19^{\text {th }}$ - and $20^{\text {th }}$-century historiography, databases.

\section{Bibliografia}

Baranowski H., Czarciński I., Bibliografia bitwy pod Grunwaldem i jej tradycji, red. M. Biskup, Toruń 1990.

Batowski A., Rękopisma księgozbioru Ossolińskich. Rękopisma dziejów polskich przez Dlugosza, „Biblioteka Narodowego Zakładu im. Ossolinskich”, t. 5, 1843, s. 41-80.

Batowski A., Niektóre rękopisma księgozbioru Zakładu Narodowego imienia Ossolińskich, Lwów 1844.

Bentkowski F., Historya literatury polskiej, t. 2, Warszawa-Wilno 1814.

Białecki A., Rękopisma Długosza w petersburskich bibliotekach pod względem paleograficznym i bibliograficznym, Petersburg 1860.

Bibliografia historii Polski, t. 1 do roku 1795, cz. 1, red. H. Madurowicz-Urbańska, Warszawa 1965.

Bibliografia historii polskiej za rok 1948, oprac. J. Baumgart, Kraków 1952.

Bibliografia literatury polskiej Nowy Korbut, t. 1-3, pod kierunkiem R. Pollaka, Warszawa 1963-1965.

Bibliografia literatury polskiej okresu Odrodzenia (materiały), oprac. K. Budzyk, R. Pollak, S. Stupkiewicz, Warszawa 1954.

Bibliografia polska 1901-1939, t. 1, A-Bars, red. J. Wilgat, red. tomu I. Olszewska, Warszawa 1986, t. 5, Cz-Dn, oprac. I. Maziarz, Warszawa 2002.

Bömelburg H.-J., Polska myśl historyczna a humanistyczna historia narodowa (1500-1700), Kraków 2011.

Brożek M., Czy Filip Kallimach jest autorem Żywotu Długosza?, „Zeszyty Naukowe Uniwersytetu Jagiellońskiego" Prace historycznoliterackie, z. 3, Filologia, z. 5, 1959, s. 11-60. 
Chevalier U., Répertoire des sources historiques du Moyen Age, t. 1, Bio-bibliographie, Paris 1877-1883.

Chevalier U., Répertoire des sources historiques du Moyen Age, t. 1, A-I, Paris 1905 (reprint New York 1959).

Chojnacki P., Jaworski R., Kaliszuk J., Węcowski P., Bibliografia źródeł drukowanych do dziejów Polski późnośredniowiecznej (1383-1506), cz. 1, Warszawa 1999.

Dawni pisarze polscy od początków piśmiennictwa do Młodej Polski. Przewodnik biograficzny i bibliograficzny, t. 1 i 5, Warszawa 2000-2004.

Dembowska M., Metoda Bibliografii polskiej Karola Estreichera, Warszawa 1970.

Dymmel P., Bibliografia edytorstwa źródeł historycznych w Polsce. Historia - krytyka tekstu - metodyka i technika wydawnicza, Lublin 2001.

Dymmel P., Pierwsza redakcja najstarszego herbarza polskiego, [w:] Ludzie i herby $w$ dawnej Polsce, red. P. Dymmel, Lublin 1995, s. 89-91.

Dymmel P., Problem autorstwa Klejnotów przypisywanych Janowi Długoszowi, „Rocznik Polskiego Towarzystwa Heraldycznego”, t. 1 (12), 1993, s. 59-75.

Dymmel P., Tradycja rękopiśmienna Roczników Jana Dtugosza. Studium analityczne ksiag X-XII, Warszawa 1992.

Dymmel P., W sprawie warsztatu edytorskiego dawnych wydań Roczników Jana Długosza, „Studia Historyczne”, R. 34, 1991, z. 3, s. 350-359.

Dymmel P., Z dziejów kodykologii w Polsce. Dziewiętnastowieczne badania nad rękopisami Roczników Jana Długosza, [w:] Z badań nad polskimi księgozbiorami historycznymi, t. 14, Wyniki i perspektywy, red. nauk. B. Bieńkowska, Warszawa 1992, s. 5-59.

Estreicher K., Bibliografia polska, cz. III, t. 4, Kraków 1897.

Estreicher K., Bibliografia polska XIX stulecia, Kraków 1870.

Estreicher K., Bibliografia polska XIX stulecia, lata 1881-1900, Kraków 1906.

Estreicher K., Bibliografia polska XIX stulecia, red. K. Estreicher [jun.], t. 4, wyd. 2, Kraków 1966.

Finkel L., Bibliografia historii Polski, cz. 1, Lwów 1891, cz. 2-3, Kraków 1895-1906.

Finkel L., Bibliografia historii Polski, cz. 1-3, Warszawa 1955-1956.

Gieysztor A., Prace nad reedycją bibliografii źródet średniowiecznych (Bibliotheca historica medii aevi) Potthasta, „Studia Źródłoznawcze”, t. 1, 1957, s. 324-326. Hrynkiewicz M. M., Bibliografia grunwaldzka za lata 1990-2009, „Komunikaty Mazursko-Warmińskie", 2010, nr 3, s. 373-409.

Janocki J. D., Specimen catalogi codicum manuscriptorum Bibliothecae Zaluscianae, Dresdae 1752.

Janocki J. D., Musarum Sarmaticarum specimina nova, Vratislaviae 1771. 
Janocki J. D., Janociana, sive clarorum atque illustrium Poloniae auctorum maecenatumque memoriae miscellae, vol. 1-2, Varsaviae et Lipsiae 1776-1779; vol. 3, wyd. S. B. Linde, Varsaviae 1819.

Joannis Dlugosii senioris canonici Cracoviensis opera omnia. Cura A. Przezdziecki, t. 1, Cracoviae 1887.

Koczerska M., Kto jest autorem Żywotu Dlugosza?, [w:] Venerabiles, nobiles et honesti. Studia z dziejów społeczeństwa Polski średniowiecznej, red. A. Radzimiński, A. Supruniuk, J. Wroniszewski, Toruń 1997, s. 507-520.

Koczerska M., Piętnastowieczne biografie Zbigniewa Oleśnickiego, „Studia Źródłoznawcze", t. 24, 1979, s. 5-82.

Korbut G., Literatura polska, t. 1-3, Warszawa 1917-1921.

Korbut G., Literatura polska od początków do wojny światowej, t. 1-4, Warszawa 1929-1931.

Kowalski M. D., Dzieje autografu katedralno-kolegiackiej części Liber beneficiorum dioecesis Cracoviensis Jana Długosza, „Studia Źródłoznawcze”, t. 46, 2009, s. 83-94.

Kuraś S., Regestrum Ecclesiae Cracoviensis. Studium nad powstaniem tzw. Liber Beneficiorum Jana Długosza, Warszawa 1966.

Łepkowski J., Sprawozdanie z czynności wydawnictwa dzieł Długosza. I, „Biblioteka Warszawska", 1859, t. 2, s. 854-863.

Łepkowski J., Sprawozdanie z czynności wydawnictwa dzieł Długosza. II, „Biblioteka Warszawska", 1859, t. 4, s. 782-787.

Łepkowski J., Sprawozdanie z czynności wydawnictwa dzieł Długosza. III, „Biblioteka Warszawska", 1860, t. 1, s. 742-756.

Mierzwa W., Bibliografia grunwaldzka, Olsztyn 1990.

Miśkiewicz B., Wstęp do badań historycznych, wyd. 4, Warszawa 1985.

Muczkowski J., Wiadomość o rękopismach Historyi Dlugosza, „Rocznik Towarzystwa Naukowego z Uniwersytetem Jagiellońskim złączonego", 1850, z. 2, s. 169-247.

Muczkowski J., Wiadomość o rękopismach Historyi Długosza, jego Banderia Prutenotum tudzież Insignia seu clenodia Regni Poloniae, Kraków 1851.

Nowak A., Złote lata bibliografii polskiej. Ludwik Finkel i jego dzieło, Warszawa 2007. Polska bibliografia literacka za rok 1948, Wrocław 1954.

Potthast A., Bibliotheca historica medii aevi. Wegweiser durch die Geschichtswerke des europäischen Mittelalters von 375-1500, Berlin 1862.

Potthast A., Wegweiser durch die Geschichtswerke der europäischen Mittelalters von 375-1500: Supplement, Berlin 1868. 
Potthast A., Bibliotheca historica medii aevi. Wegweiser durch die Geschichtswerke des europäischen Mittelalters bis 1500. Bd. 1-2, wyd. 2, Berlin 1896 (reprint Graz 1957).

Przezdziecki A., Énumeration et déscription sommaire de 64 mss., 6 fragm. et 10 abrégés de l'Histoire de Pologne de Jean Długosz (dit Longin), Cracovie 1870.

Przezdziecki A., Piąte sprawozdanie z czynności wydawnictwa dzieł Długosza wraz $z$ krótkim opisaniem po dziś dzień znanych 64 rękopisów, 6 ułamków i 10 streszczeń Historii polskiej Długosza, „Biblioteka Warszawska”, 1870, t. 2, s. 31-40.

Przezdziecki A., Sprawozdanie z czynności wydawnictwa dzieł Długosza (IV), „Biblioteka Warszawska”, 1865, t. 1, s. 446-455.

Repertorium fontium historiae medii aevii, primum ab Augusto Potthast digestum, nunc cura collegii historicorum e pluribus nationibus emendatum et auctum, t. 2 i 4, Romae 1967-1976.

Stańczyk Z., Jan Dlugosz. Bibliografia podmiotowo-przedmiotowa, „Ziemia Częstochowska”, t. 43, 2017, s. 87-123.

Vincentiana. Materialy do bibliografi, zest. K. Kollinger, [w:] Onus Athlanteum. Studia nad Kroniką biskupa Wincentego, red. A. Dąbrówka, W. Wojtowicz, Warszawa 2009, s. 476-527.

Wiszniewski M., Historia literatury polskiej, t. 4 i 7, Kraków 1842-1845.

Zeissberg H., Die polnische Geschichtschreibung des Mittelalters, Leipzig 1873.

Zeissberg H., Dziejopisarstwo polskie wieków średnich, t. 2, Warszawa 1877. 